\title{
Securing the blue: political ecologies of the blue economy in Africa
}

\author{
John Childs ${ }^{1}$ \\ Christina C. Hicks \\ Lancaster University, UK
}

\begin{abstract}
The Blue Economy concept is being embraced enthusiastically in Africa, both internally and externally. However, this new framing creates and calls for new understandings of how actors and places relate to one another, control, and create meaning and value. Thus, understanding the ocean - and its conceptual and material fabric - in this context, is a matter of political ecology, raising a number of questions that extend across geographies, spatio-temporalities, and political actors, both human and more-than-human. In this article, we flesh out these questions. An understanding of historical efforts to legally secure oceanic space can help contextualize the emergent African blue economy, one which we propose rests predominantly on the notion of 'security.' We demonstrate how resources are economically, environmentally, and politically 'secured' as they are first constructed as economic objects of accumulation, then militarized as matters of geopolitical security, and finally controlled through technologies of monitoring, surveillance, and resistance. The 'security' of the blue growth agenda and its effects operates across different temporal and spatial dimensions and are realized in different ways across the continent as explored in the six articles in this Special Section.
\end{abstract}

Keywords: blue economy, deep sea mining, political ecology, oceanic space, security

\section{Résumé}

Le concept de l'économie bleue est adopté avec enthousiasme en Afrique, tant à l'intérieur qu'à l'extérieur. Cependant, ce nouveau cadrage crée et appelle de nouvelles compréhensions de la façon dont les acteurs et les lieux sont liés, et comment ils contrôlent et créent le sens et la valeur. Ainsi, la compréhension de l'océan - et de son tissu conceptuel et matériel - relève, dans ce contexte, d'une question d'écologie politique, qui soulève un certain nombre de questions qui couvrent des zones géographiques, des spatio-temporalités et des acteurs politiques, humains et plus que humains. Dans cet article, nous développons ces questions. Une compréhension des efforts historiques pour sécuriser juridiquement l'espace océanique peut aider à contextualiser l'économie bleue africaine émergente. Nous soutenons que l'économie bleue repose principalement sur la notion de «sécurité». Nous montrons comment les ressources sont «sécurisées» sur le plan économique, environnemental et politique, car elles sont d'abord construites en tant qu'objets économiques d'accumulation, puis militarisées en tant que questions de sécurité géopolitique, puis contrôlées au moyen de technologies de surveillance et de résistance. La "sécurité" de l'agenda de l'économie bleue et ses effets opèrent dans différentes dimensions temporelles et spatiales et se concrétisent de différentes manières sur tout le continent, comme l'expliquent les six articles de cette section spéciale.

Mots-clés: économie bleue, exploitation minière hauturière, écologie politique, espace océanique, sécurité

\section{Resumen}

En África, el concepto de Economía Azul está siendo adoptado con entusiasmo tanto interna, como externamente. Sin embargo, este nuevo encuadre crea y convoca a nuevos entendimientos de cómo actores y lugares se relacionan unos con otros, además de controlar y crear significado y valor. Por tanto, entender el

\footnotetext{
${ }^{1}$ Dr. John Childs and Prof. Christina C. Hicks, Lancaster Environment Centre, Lancaster University, UK. Emails: j.childs "at" lancaster.ac.uk, christina.hicks "at" lancaster.ac.uk. Acknowledgements: we thank the authors and many referees that have contributed to this JPE Special Section, including a reviewer of this introductory article. Writing was assisted by an EU ECR fellowship, FAIRFISH (Hicks) and a UK ESRC fellowship ES/N016548/1 (Childs). This is the introduction to John Childs and Christina Hicks (eds.). 2019. "Political ecologies of the blue economy in Africa", Special Section of the Journal of Political Ecology 26: 323-465.
} 
océano -en sus dimensiones conceptual y material- en este contexto, es un tema de ecología política, al formular algunas preguntas que se extienden por diferentes geografías, espacio-temporalidades y actores políticos, tanto humanos, como más-que-humanos. En este artículo damos forma a estas preguntas. Entender los esfuerzos históricos para asegurar los espacios marinos oceánicos de manera legal, es fundamental para contextualizar la emergente economía azul africana, la cual, proponemos está basada en la noción de "seguridad". Aquí demostramos cómo los recursos son económica, política y ambientalmente "asegurados" cuando inicialmente son construidos como objetos de acumulación, luego militarizados como asunto de seguridad geopolítica, y finalmente, controlados a través de tecnologías de monitoreo, vigilancia y resistencia. La "seguridad" de la creciente agenda azul y sus efectos, operan a través de varias dimensiones temporales y espaciales, y son realizadas de diversas maneras a lo largo del continente, tal como se explora en los seis artículos de esta sección especial.

Palabras clave: economía azul, minería de fondos marinos, ecología política, espacio marino oceánico, seguridad

\section{Introduction: mobilizing the blue economy in Africa}

The 'Blue Economy' has emerged as a concept over the past two decades from a diversity of fora, but most notably within environment or development policy and practice (Hoegh-Guldberg et al. 2015; Patil et al. 2016; UNECA 2016). However, 'Blue Economy' ideas have a longer history, building on the green economy, and closely aligned with sustainable development (UN 2012). Proponents of the blue economy make bold promises to improve human wellbeing and equity, reduce environmental risks and scarcity, and foster national and regional cooperation (Pauli 2010; UNECA 2016). Within government departments globally, but here focused on Africa, 'Blue Economy' perspectives engender a view of the oceans as a source of 'wealth and prosperity' (Gov Seychelles and Commonwealth 2018), whose 'economic potential needs unlocking' (RSA 2015). Yet, beyond technocratic procedures such as Marine Spatial Planning, it remains unclear what is new in the processes of resource extraction and wealth generation that will resolve the tensions inherent in these aspirations, or how the Blue Economy will avert the social and environmental justice concerns of the Green Economy (Cavanagh and Benjaminsen 2017).

Describing the potential contribution to human wellbeing provided by aquatic and marine spaces (particularly seas, oceans and their resources), the 'Blue Economy' and 'blue growth' agenda have been mobilized as a conceptual frame, policy discourse, and as set of practices across the globe. Here we recognize the diversity that exists in interpretations of the blue economy concept, and that this diversity engenders a vagueness that enables the blue economy to encompass divergent visions and ideologies; but, to also represent differing and conflicting agendas. In this Special Section, we engage with the diversity of ways the blue economy concept is interpreted, and its implications. This work follows a recent upsurge in interest in which the ocean is prefigured as significant to planetary futures, and where it is seen as a more central actor in geopolitical formations. Such a turn towards 'critical ocean studies' (Deloughrey 2017) within social thought across the world has sought to foreground the unique ontological (Steinberg and Peters 2015) and postcolonial (Gilroy 1993; Deloughrey 2007) provocations wrought by the sea. These welcome efforts to bring the ocean into political view have aimed, on the one hand, to decolonize its epistemologies and ontologies (i.e. to think about moving beyond euro-centric ways of knowing and constituting the ocean). On the other hand, they have tried to spatially recalibrate the ocean away from a flat and inert space towards a vibrant, dynamic and voluminous one. However, even in the face of this scholarly work, capital has continued to prove adept at capturing and reducing oceanic diversity into an economic object of potential through the simple and colorful epithet: 'blue.'

With limited exceptions ${ }^{2}$, there has yet to be a sustained critical analysis which draws upon the fact that 'blue growth' is simultaneously an economic, social, biological and geologic project. Viewing the blue economy in this way is to understand the ocean (and its conceptual and material fabric) as a matter of political ecology

\footnotetext{
${ }^{2}$ See for example the special issue in the journal Dialogues in Human Geography in which the 'blue economy' is debated as a specific 'moment' of bio-economic relations (Winder and Le Heron 2017).
} 
and this raises a number of questions fleshed out in this article, and exemplified by the others in this Special Section. These questions are driven by an understanding that the blue economy framing of the ocean does the work of 'securing' it as a space for specific economic, environmental and military agendas and interventions. Thus, what are the political implications for scripting and 'securing' oceans and water as part of an economic imaginary of 'progress' and 'growth', and of separating it from landed 'green' economies'? As the 'blue' (like the 'green') is reworked spatially into a language of new 'frontiers' (Silver and Campbell 2018), 'opportunities' and 'alternative sustainabilities' (Cavanagh and Benjaminsen 2017), what new political ecologies might exist? What (new) ways of 'knowing' the ocean are either hidden, marginalized or revealed by framing and militarizing the 'blue' as something to be 'protected'?

We address these theoretical questions in the context of the African continent. This is for two major reasons. First, the blue economy narrative has been nowhere more enthusiastically and explicitly adopted in recent times than in an African context. The Africa Union's Agenda 2063 - the key policy framework for the continent's future socio-economic development - makes explicit reference to the concept (African Union 2014) whilst the UN Economic Commission for Africa (UNECA) developed a 'policy handbook' in 2016 which describes maritime development as "the new frontier of African Renaissance" (UNECA 2016). Industries and practices that range from the established (such as aquaculture, offshore oil and gas extraction, fishing and tourism) to the prospective (deep-seabed mining, blue carbon sequestration, financing through 'blue bonds') are all seen as part of a future familiarly parsed as a 'motor for development.' Indeed, Africa's blue economy is imagined as mapping directly onto the UN Sustainable Development Goals (SDGs), particularly SDG 14 which encourages the "sustainable use [of] oceans, seas and marine resources for sustainable development" (UNECA 2016: 9). Secondly, understanding the blue economy in the African context is important not only in a policydriven sense, but also in metaphorical terms. Many commentators excitedly associate Africa's relationship with the blue economy as being a contemporary expression of the continent's 'rising power' narrative, in which the 'blue' is imagined as "a major contributor to continental transformation and growth" (African Union 2014: 3). Similarly, buoyed by a reimagining of the African context as composed of a majority of coastal states, individual states on the continent are seen as 'blue' with jurisdictional areas totaling three times the size of its landmass. As the former executive secretary of UNECA, Carlos Lopes put it, the blue economy "is a timely contribution to help the continent harness its "new frontier"" (UNECA 2016: xii).

However, such impulses towards 'frontiers' and 'progress' demand critical interrogation in the context of such new modes of accumulation and the spatial fixing and exploitation of 'new' resources. How, for example, are the 'resource'- and 'state'- making designs of the blue economy challenged and resisted? The blue growth narrative in Africa implies a homogeneity to the continent that must be critiqued. When and how do individual states, each with their own relational and individual socio-histories, come to be reworked as 'blue'? In the second Section, we contextualize this by outlining a profound diversity of approaches for understanding the political ecologies of the blue economy in Africa. This multiplicity extends across geographies, spatiotemporalities and the political actors involved, human and more-than-human. Section Three situates historical efforts to legally secure oceanic space, whilst in Section Four we develop our main argument: that the African blue economy predominantly rests on the notion of 'security.' Resources are economically and politically 'secured' as they are first constructed as economic objects of accumulation and then militarized as matters as geopolitical security. In relation to this, the environmental 'security' of the blue growth agenda and its effects operates across different temporal and spatial dimensions as concerns around, for example, pollution and climate change are realized in different ways across the continent. We conclude in Section Five by introducing the articles in this Special Section and we situate them collectively as necessarily rethinking the 'place' of the blue in blue economy narratives.

\section{Conceptualizing the blue economy in Africa}

An African 'blue economy' is defined by its heterogeneity in several ways. Here we focus on two interrelated aspects: its spatio-temporalities, and the political actors that frame the breadth of political ecological contexts across the continent. In the first instance, it should be made clear that for many African 
states including those in the Southern African Development Community ${ }^{3}$ (Ngwawi 2018) the material presence of a coastline is not a necessary prerequisite to inclusion in the blue economy narrative. Instead, all African countries, including landlocked states, can be thought of as political agents in the blue economy and their economic futures are strongly associated with issues described as 'marine.' For example, since 2011, the sharp downturn in the number of piracy incidents in African waters has had a beneficial impact on the continent's landlocked countries as well as coastal states (Dunne 2015). Premised on the historical economic interdependence of landlocked and neighboring coastal states in Africa (see Figure 1), this improved maritime security environment is seen as a key part of blue economy strategies. The argument proceeds that the benefits of 'secure' coastal states 'spill over' to landlocked states due to lower transportation and improved access to maritime countries' economies (ibid.).

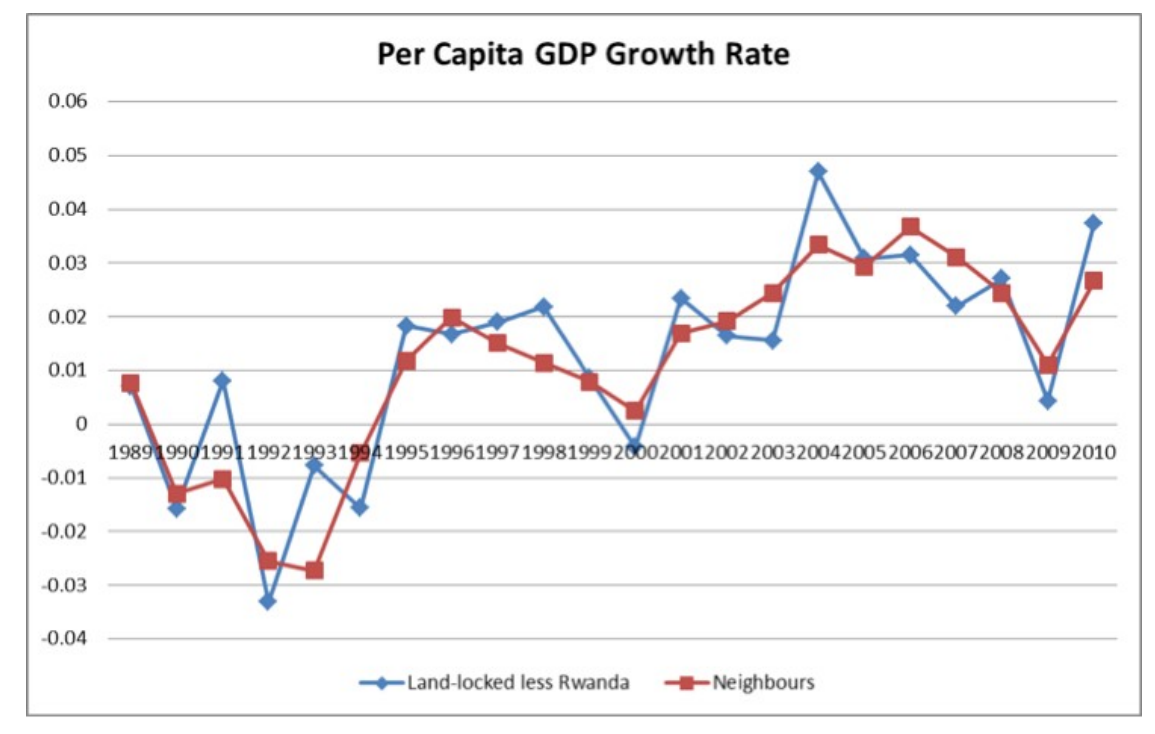

Figure 1: Landlocked and sea-access neighbors' per capita growth in Africa. (Source: Dunne 2015)

Another example where the African blue economy is extended further than coastal states relates to deepsea mining (DSM). The DSM sector has emerged as a new resource frontier for many governments seeking to mobilize its geopolitical and economic potential (Childs 2018). Attracted by the so-called 'opportunities' presented by DSM, the UNECA policy handbook on the blue economy highlights the "motivation for African States to explore avenues for their enhanced participation in the international seabed regime" (UNECA 2016: 56). Individual (coastal) member states retain rights over seabed mineral deposits that lie within the $200 \mathrm{~km}$ Exclusive Economic Zone of a country's landmass. Yet minerals found outside EEZs but on the seabed in the 'Area' beyond national jurisdiction, are designated as the 'common heritage of mankind' and are regulated by the International Seabed Authority (ISA), a United Nations organization developed under UNCLOS (the United Nations Convention on the Law of the Sea). What 'common heritage' comes to mean in the African context is open to question, especially when it comes to the role of landlocked countries. According to the ISA itself, in order for the "deep seabed to contribute to a sustainable Blue Economy narrative", a holistic understanding of Africa's spatiality is needed (ISA 2017: 40):

\footnotetext{
${ }^{3}$ The Southern African Development Community(SADC) is made up of 16 distinct states, six of which do not have coastlines (SADC 2018).
} 
The question on how to reconcile regular mining activities of landlocked African countries visà-vis deep seabed mining is something that African countries can answer collectively, through regional cooperation and partnership. (ISA 2017: 26)

These examples suggest that Africa's blue economy is about more than physical connections with water. Important though coastal states are to the concept, their historical role as a "primary conduit of human interface" has been refashioned as postcolonial state-building and closure of "routes of connectivity" has ushered in new geographic imaginaries of the human/sea relationship (Prestholdt 2015: 441). Moreover, as the idea of 'Africa' has broadened alongside the enormity of global migrations and histories of slavery and indentured labor (Mudimbe 1994), 'blue Africa' is about connection as much as it is about a fixed sense of place. The continent's diaspora is psychologically and economically invested in the continent's 'blue economy' in very significant ways, yet it remains peripheral to most common discussions of the concept.

It remains the case, however, that the blue economy narrative is spatialized most overtly in the geographical imagination for those with significant coastlines. This is particularly true for small-island states. For states like Seychelles and Mauritius, the blue economy affords an opportunity to recast themselves as significant economic actors by incorporating a territorialized ocean into their imaginary (see, for example, Schutter and Hicks 2019). This reworks colonial 'island imaginaries' that have historically constructed these "small islands as empty, isolated and unconnected" in order to justify colonial practices of exile, incarceration and military infrastructure building (Kothari and Wilkinson 2010: 1396). Even allowing for the contemporary mutation of these colonial stereotypes of exoticism and solitude into touristic enactments of 'paradise', the blue economy promises a geographic imaginary that goes further. By moving beyond imaginaries that look inwards at the island as coastal (and thus terrestrially bounded) and that represent it in stereotypical ways, these states now seek to look outwards to the ocean and to incorporate it as a key part of national development strategies. In doing so, they provide a compelling example of "small island states on the periphery of the world economy...continuously reinvent[ing] themselves and find[ing] new ways to attract global flows" (Kothari and Wilkinson 2010: 1409).

Put yet another way, the discourse and material practices of the blue economy are attempts to 'secure' oceanic space and to script it into the 'language' of capital. The ocean thus emerges as a very particular kind of 'volume' (Elden 2013), one which is variable, often unstable in its biophysical characteristics and dynamic and unpredictable over time. As Grundy-Warr et al. point out, "scholars examining fluid, dynamic and mobile spaces of the ocean recognize that there is a great deal more to maritime space than legal-political apportioning and partitioning processes" (Grundy-Warr et al. 2015: 94). Quite how capital does this work of 'securing' materially diverse oceanic space to its own ends is a question that invites much fuller theoretical engagement. Indeed, we only begin to address this with a few illustrations in the next Section. Yet, for all the thinking about the spatialities of Africa's blue economy, in all their forms, there is also an invitation to engage with its temporalities.

By way of one important example, the historical legacies of colonialism are inseparable from the power structures that help to define the relationship between the ocean and the political economy across the continent. Its effects, particularly those forged in part in transoceanic crossings, create an "aesthetics that imaginatively populates the sea in an act of regional historiography and ancestral memory" (Deloughrey 2017: 35). Thinking historically, one might ask what the effects of such heritage are for the present and future conditioning of the 'blue economy' especially when they collide with notions such as the 'common heritage of mankind.' Other temporalities relate to environmental pollution and degradation events. What forms of 'slow violence' (Nixon 2011) might be realized through the ramping up of activities such as industrialized fishing or deep-sea mining? Yet it is not just about looking backwards in time to uncover events and processes, but forwards in a Janus-faced duality. As objects of the blue are transformed into commodities, they will be speculated upon, and traded as 'futures' on commodity markets globally. Additionally, finance and capital are already being mobilized in order to ensure oceanic health and to facilitate blue growth agendas. One example of this, demanding of more critical attention, can be found in the Seychelles where 'blue bonds' will be used to "finance the transition to the sustainable management of its small-scale artisanal fisheries" (FAO 2017). Countless examples remain (many 
of them taken up in this Special Issue), but thinking about the blue economy demands an engagement with the ocean's unique spatio-temporalities.

The blue economy's diversity is also captured through the wide array of political actors involved, notwithstanding the fact that a narrower, state-focused set of actors are currently engaged by official discourse. Narratives surrounding the blue economy has been overwhelmingly dominated by governmental and intergovernmental actors such as the United Nations, European Union, African Union, and the Organisation for Economic Cooperation and Development (Voyer et al. 2018). Opportunities to explore and progress this agenda have often been in exclusive forums such as The Economist's annual World Ocean Summit that tend to be dominated by business and finance sectors. Consequently grass roots resistance, particularly from the small scale fisheries sectors affected by the outcomes of such events, is growing (WFFP and WFF 2013, 2015a, 2015b). A disconnect between international aspirations for the blue economy, and the practical realities and consequent injustices of its implementation, is increasingly apparent (Barbesgaard 2018; Bennett et al. 2015).

In addition to the more obvious cast of human actors involved or excluded, are those less well studied, in 'more-than-human geographies.' They echo recent work in political ecology in which theories of '(state) power' and governance have given increased attention "to the materiality/biophysicality of resource conditions" (Harris 2017: 92; Clarke-Sather et al. 2017; Meehan 2014) as well as spiritual geographies (Theriault 2017). For the blue economy, this means not just studying the materiality of the ocean along with its politics (Lehmann 2013) but thinking 'through' it. In other words, a turn towards a 'wet' (Steinberg and Peters 2015) or 'sea' (Deloughrey 2017) ontology enables a relationship between the ocean and "maritime subjects and objects [that] can move across, fold into, and emerge out of water in unrecognized and unanticipated ways" (Steinberg and Peters 2017: 261).

What these new political formations will look like as the 'blue economy' narrative develops is open to possibility. Human political actors will clearly remain important. The state, International Financial Institutions, the corporation, NGOs and activist groups will continue to come together in ways that make the blue economy political. Yet they will also be shaped, constrained and enabled by political forces that can be found beyond a simple engagement with the human, including the material or the spiritual. As Campling and Colas argue, "the sea is a crucial site for the valorization of capital - be it through extraction or transport - and a major bio-physical obstacle to its reproduction" (Campling and Colas 2018: 789). This has been shown historically where the Atlantic Ocean (in particular) acts as "an unmarked grave site" for slaves lost or thrown overboard (Deloughrey 2017: 35). As Derek Walcott memorably put it, the seas act as a "grey vault" that "locks up" specters of a history intertwined with capital (Walcott 1987). Yet, as he continues, the ocean also "kept turning blank pages, looking for history", indicating the reproduction of the ocean and the memories that it 'holds' as simultaneously a site of ongoing capital accumulation (Baucom 2005). What new forms of bio-political, spiritual or material actor might shape the blue economy narrative in the present and future, and what role does the heritage of the term play in its formation (Lehman 2018)? The following Section briefly outlines the historical-legal securing of oceanic space and how these framings relate to Africa.

\section{Historical efforts to secure the oceans: mare clausum versus mare liberum}

Efforts to secure and free the ocean's surface for transport and communication, have a long history, tied closely to patterns of power, competition, and trade (O'Connell 1982: 1). Prior to the sixteenth century, Africa was relatively isolated. The east African coastline was one exception where contact with the Islamic world and Middle East enabled the gradual spread of Islamic ideas and practices. Subsequently, marine territorial claims have played out in a similar way to on land, with western interests dominating over the past 400 years (Colombos 1967: 63; Steinberg 2001: 97; UN 1958: 205). As Europeans began to explore the world, early claims were focused on securing the seas for transport, facilitating the accumulation of wealth. Various naval powers would claim, through Mare Claussum - the right of any nation to control the seas - large tracts of oceans as closed to other naval powers, thus securing their trade routes and economic power (Colombos 1967: 63, Steinberg 2001: 97). In the fifteenth century the Portuguese dominated and controlled these routes which led the Dutch, in 1608, to challenge Mare Claussum and instead called for the right for all nations to freely access and navigate the sea, instigating Mare Librium: 
The sea is common to all, because it is so limitless that it cannot become a possession of anyone, and because it is adapted for use by all, whether we consider it from the point of view of navigation or fisheries. (Grotius 1916[1609]: 28)

Mare Librum, or the right of access to all seas, and technological breakthroughs in innovations in shipping and transport, enabled European domination of the world economy (Hugill 1993). These powers were felt most starkly in West Africa with the rapid growth of the trans-Atlantic slave trade, connecting the region to the Americas through the supply of 'free' labor, and fueling economic growth in Europe.

The early twentieth century saw a broadening of how the oceans were viewed as significant (Steinberg 2001). Further technological developments enabled the extraction of deep-sea fish stocks. The placing of the first off-shore oil well off the coast of Louisiana in USA in 1937 changed the emphasis of the sea from "an avenue of transportation and communication, to an important economic zone for the exploitation of natural resources" (UN 1958b:114 and Schrijver 2008: 204). This shift in the significance of ocean space towards a resource to exploit (for fish, oil, and gas) and later to conserve, spurred further discussions over the extent of national jurisdiction over natural resources; driven primarily by US led concerns to secure oil and fish stocks (US 1945a: 12303; US 1945b: 12304). International discussion regarding the extent of a nation's authority over waters fell into two broad groups; countries with large long-distance fishing fleets, in Europe and America, favored narrower zones, whereas countries with limited long-distance capabilities, as in Africa, favored larger ones. Eventually, an Exclusive Economic Zone (EEZ) of 200 nautical miles was decided within which coastal states have "exclusive rights to living and non-living resources, but for all other purposes high-seas freedoms prevail" (Steinberg 2001:149; UN 1982). For some, the establishment of a two-hundred nautical mile zone represents the "most significant, and yet largely unremarked, twentieth century remapping of the globe" (Deloughrey 2017: 32).

Although the designation of EEZs were intended to secure national revenue through licensing to countries with fewer fishing capacities, global inequalities remained, legitimizing the flow of fish and minerals from areas of weak governance and control, most notably West Africa, to more powerful nations (e.g. see Pauly et al. 2014). Current legal definitions, where nations have the right to exercise sovereign control over their coastal waters, but within which foreign ships are allowed free passage (UN 1983), privileges countries with greater economic and technological capacity, maintaining patterns of trade and exploitation predicated on an imbalance in power.

The importance of the sea for transport and patterns of trade have persisted. In 2017, marine transport accounted for $70 \%$ of global trade by value and $80 \%$ by volume (UNCTAD 2017). Because Africa's ports were historically built by European imperial powers to secure the flow of goods and resources, most current trade in Africa is with the EU, accounting for $4 \%$ of global container trade. However, the landscape is changing with Chinese funding for current port expansions and harbor developments, from Mombasa in Kenya, to Accra in Ghana (Bond 2019). Furthermore, in many instances, these coastal developments are connected to landlocked African countries through Chinese-funded railways, securing routes for the flow of goods and resources from Africa to the rest of the world, on Chinese terms. While historical connections to Europe and America continue to shape the economic and geopolitical relationships different African nations forge with the world, new relationships are emerging. In what follows, we open this up to political ecological critique.

\section{Securing Africa's blue economy in space and time}

Part of the political utility of the term 'blue economy' is its semantic breadth. It can be mobilized to usher in particular forms of political ecological practices by a wide range of actors and industries whilst simultaneously avoiding any sense of a commonly agreed definition. Avoiding such conceptual agreement is important not only because, "the potential for miscommunication is great" (Eikeset et al. 2018: 178) but also because it sidesteps any critical engagement with, and thus accountability, of those that invoke the term. Consequently, whilst the blue economy's discursive multiplicity may be useful it is also "one of its biggest constraints" to sustained and focused critique (Hadjimichael 2018: 158). Reducing the diversity of perspectives on the term to a singular 'economy' becomes a matter of political economic security, whereby the specificity of 
context is overlooked and particular framings become implied in order to reproduce existing modes of capital accumulation and open up new frontiers for profit. In other words, this forecloses the possibilities of imagining and understanding the ocean as about anything other than growth. Once the blue economy is couched in the language of 'frontiers', it becomes a discursive and material space of 'opening' and 'closing' (Steinberg 2018), which need to be simultaneously 'secured' in various ways.

It might well be that in the African context, the blue economy can be situated at the confluence of discourses on, for example, development, sustainability and placelessness (Germond-Duret 2018). In other words, it becomes a political economic project in which the promises of capitalist expansion shape the sea into a commodity that is inert, without place and history. In doing so, the ocean is fixed and secured not just spatially, but also temporally as the violence of colonial histories on the world's oceans are ignored in favor of a future ocean economy that is about 'sustainable development.' This denies not only acts of memorializing the violent, imperial "convergence of environment and history", but also the lively material properties of oceanic space itself (DeLoughrey 2107: 33). Indeed, there is a clue in the analogous framing of the blue economy as 'blue growth' in which progress is presented as linear and inevitable, arising from a flattened sense of time and space. Specific policy proposals that are inhered become, without critical interrogation, a kind of 'antipolitics' that preclude the possibilities of doing ocean governance differently (Barbesgaard 2018). Only recently have there been any critical alternatives offered to these unimaginative political aesthetics with calls for moving towards 'blue degrowth' (Hadjimichael 2018). ${ }^{4}$ Against this background, this Section thinks through the various modes of 'security' invoked by the emergence of a 'blue economy' in Africa. These range from the economic to the environmental, from the militaristic to the geopolitical forms of the notion, albeit it with overlapping dynamics.

Although the moniker suggests otherwise, these different forms aren't just confined to the economic securing of blue objects such as the oceans, rivers and coastal zones. Geopolitical security, particularly the establishment of a 'security of supply' for particular 'blue' resources, are regularly assumed by commentators to be central to its narrative. Such geopolitical posturings are perhaps most readily associated with the polar regions and in the South China Sea, part of a series of 'sovereignty games' (Hannigan 2017) where the most powerful national actors (for example Russia, China) are often reported as expressing imperialist intentions. They are also common to the African context too. Perhaps the best example of such a sovereignty dispute lies inthe case of the Chagos Archipelago, nominally part of the British Indian Ocean Territory and for 50 years the site of a UK-US military base. Between 1968 and 1973, over 2,000 indigenous Chagossians (Îlois) were forcibly migrated to Mauritius, Seychelles, and the UK in order to facilitate the geopolitical securing of militarily strategic Indian Ocean space. The United Nations General Assembly referred a decades-old territorial dispute between the competing claims of Mauritius and the UK over the islands to the International Court of Justice in 2017. Yet in a further ecological twist, the UK's recent moves to designate the area as a Marine Protected Area (MPA) in the name of ecological sustainability, can be seen to coincide, perhaps deliberately, with the concurrent sovereignty claims at play. Whatever the outcome of these developments, what seems clear is that the securing of oceanic space through a "MPA designation that precludes the return of local people to the Chagos archipelago will, from a human rights perspective, also sustain the injustice that the previous removal of these people represents" (De Santo et al. 2011: 260). It is truly, in other words, a question of political ecology.

Casting the dynamics of Africa's blue economy as a kind of zero-sum 'great game' between competing nation states is reductive, not least because it marginalizes the materiality of the ocean itself as an important political actor. Oceanic politics is not only some Westphalian version of a realist geopolitics played out on a static surface, but it is shaped by a voluminous and dynamic materiality in which its geophysical qualities profoundly matter (Lehman 2013: 52). In Namibia for example, the physical properties of marine phosphate environments shape the capitalist landscape that is emerging to secure their extraction. As Carver (2019) notes, it is the unique interrelationship between oceanic currents, the super-abundance of phosphorite nodules off the Namibian coast and an ecosystem predominantly made up of smaller organisms that gives way to the patchy

\footnotetext{
${ }^{4}$ See for example Maria Hadjimichael and Irmak Ertor's forthcoming special issue on 'Blue Degrowth' scheduled for publication in Sustainability Science in late 2019/early 2020.
} 
distribution of phosphate deposits. These physically uneven properties themselves beget uneven forms of resource control which can be divided into discrete concessions when the concession holder is sovereign (ibid.).

Another example relates to Seychelles where the blue economy narrative has provoked a new imaginary of economic development based on a newly rendered sense of territorial significance (Schutter and Hicks 2019). As Ronny Jumeau, erstwhile Seychelles ambassador for Climate Change memorably put it, "our islands may be small in land area, but we morph into large ocean states once our exclusive economic zones are factored in" (Jumeau 2013: 2). Invoking a kind of transformative, territorial magic that reworks the state as a more powerful actor, governments of Small Island States (SIDs) such as the Republic of Seychelles "are taking the opportunity to articulate their preferred development paths and invite/negotiate in EEZ arrangements with various partners" (Silver et al. 2018: 1; Schutter and Hicks 2019). For SIDs in Africa, the blue economy centers the ocean as a key motor for development by foregrounding its physical extent and properties (Silver et al. 2015). These qualities, in part, provide the physical geographic basis for policy initiatives such as the 'debtfor-nature' swaps currently being promoted by the Republic of Seychelles (Schutter and Hicks 2019; Silver et al. 2018). These sorts of policies can be read as a biodiversity conversation familiar to environmental governance strategies in landed contexts (Kay 2018; Sullivan 2013), yet here it is one attuned to the ocean. Calibrated this way, what new forms of environmental security might be designed under the rubric of the blue economy in order to (re)produce a financial sense of security in the future?

The blue economy is being 'secured' environmentally across the continent of Africa in a number of contexts. One obvious source of environmental insecurity being addressed is plastic waste. Plastic waste entering marine environments is not just from land-based origins, but also from poorly managed aquaculture (e.g. polystyrene buoys) and discarded fishing gear (Jambeck et al. 2018: 258). In an early reminder that the political ecologies of 'marine' pollution are intimately bound up with economic and social imperatives and practices on land, the implications for the African continent are daunting. Twelve million people are directly "engaged in Africa's fisheries sector" whilst over half of animal protein intake comes from fish in countries such as Mozambique, Sierra Leone and Tanzania (ibid.). Coalitions across the continent are beginning to form, such as the African Marine Waste Network - a network of governments, business, academia and civil society that represents the 38 African coastal and island states. Their aim is "to find solutions to Africa's marine waste problem that cater to African circumstances and cultures" (ibid.). Similar initiatives have a long history in Africa, from 'Flipiflopi' to 'Ocean Sole', both of which seek to repurpose waste plastic products into artistic representations of African heritage. Important though such interventions might be, they will need to navigate a paucity of reliable data (Jambeck et al. 2018) and confront the challenges and politics of knowledge exchange across diverse cultural traditions, industries and national policy frameworks in order to provide effective responses to escalating levels of plastic pollution.

Marine waste and pollution all leave a physical trace in oceanic space but they also reveal much about the political economic systems in which they were forged. This, in turn, opens up the tangled question of responsibility, not just for tracing accountability (i.e. who created that waste?) but also for efforts towards securing and conserving marine space (i.e. who should protect the ocean from waste flows?). Instrumental in thinking this through has been the work of researchers addressing 'marine cultural heritage', not least in Africa, and the global policy turn to preserve "all traces of human existence having a cultural, historical, or archaeological character which have been partially or totally under water, periodically or continuously, for at least 100 years" (UNESCO CPUCH 2001). Motivated by the pressures of global environmental change being placed on such sites, scholars at the forefront of this work ask, "how are historical traces of biophysical and sociocultural life recorded by the ocean and made available for analysis and interpretation in the present? Who owns these traces, how shouldthey be managed, and who is responsible for their preservation?" (Lehman 2018: 1). Individual policy responses from African states are beginning to emerge that aim to tackle these questions, such as a proposal for an underwater cultural heritage museum and "a regional training centre in underwater archaeology" in Malindi, Kenya (UNESCO 2017).

In the African context, such questions of heritage are not easily confined to narrow policy definitions provided by UNESCO. As Lehman notes, they "barely approach the far more radical ideas of postcolonial, subaltern, and Black studies scholars and writers when it comes to historical ties between human culture and the ocean, such as those forged in the horrors of the Middle Passage" (Lehman 2018: 8). Indeed, proponents 
of the African blue economy must find ways of not just recognizing the systematic violence wrought by slavery upon the continent's diaspora in the past, but of making sure that other forms of economic and environmental violence are not reproduced in the present and in future. And so we might ask, "what will future archaeologists make of the marine traces of hundreds of sunken migrant ships in the Mediterranean" (ibid.)? Similarly, we could extend this questioning to the biophysical reminders left by piracy, port expansion and deep-sea mining. Guiding concepts such as the 'common heritage of mankind' - the current designation for resources found on the deep-sea bed in areas beyond national jurisdiction - hint at the recognition that future political possibilities are inextricably linked to past human action. However, who is the 'mankind' being described and is the term effective at securing historically marginalized human actors (for example women and/or those in the global South) and more-than human political agents into the forging of new worlds yet to come?

It remains that the case that critically attuned analyses of the links between environmental security and the blue economy remain the exception rather than the rule. Most work tends to see environmental security as an enabling precursor to so-called sustainable blue growth. A common refrain might read, for example that "the link between maritime security and blue economy growth is evident: environmental degradation fuels insecurity, specifically as the poverty and marginalization of coastal populations stimulate illicit activities and even radicalization" (Potgeiter 2018: 51). Yet such approaches arguably do less work in connecting security to blue growth as they do in separating aspects of them. This is not least the case in its treatment of the human in conceptualizing security: in this formulation, human agency itself is 'secured' as the category that threatens and is threatened by nature (Cudworth and Hobden 2017). Thinking through the continent's more-than-human engagements with the blue economy becomes a vital project when thinking through the politics of environmental security.

Finally we turn to the militarized securing of the blue economy. The historical conception of the sea as placeless, wild and ungovernable has been cemented by histories of piracy that have been a widespread feature of the oceans for centuries. The coupling of the concentration of wealth through the monopolizing of trade and the channeling of this through narrow routes in the Mediterranean during the Mercantile era provided ideal conditions for piracy to flourish. This, in turn, encouraged coastal states to seek further control of their waters (Semple 1931; Steinberg 2001). Today, piracy remains common, particularly in East and West African waters, and efforts to secure marine resources have largely mirror historical patterns.

In the 1990s the number of piracy incidents in Africa began to increase, with a dramatic surge in East Africa in 2007 (see Figure 2). In response to the rapidly escalating number of incidents from Somalia, in 2009 the International Maritime Organisation sponsored a meeting in Djibouti to develop a regional response. The Djibouti code of conduct (DCoC) was subsequently signed, and then revised in 2017. The DCoC served as a framework to build counter-piracy capacity through training, improved legislation and communication, funded in part by the European Union (Kraska and Wilson 2009). Ever since, considerable investments have been made into military and private security interventions in the region which dramatically reduced the rate of attacks from nearly 200 in 2009, to 16 in 2013 and have kept them low (One Earth Future, Figure 2).

Notwithstanding the success of reducing violent incidents in the region and the real threat to international fishing and transport vessels posed by piracy, the speed and spatial scale of response has been remarkable. Particularly, given the concurrent significant threat to geopolitical security posed by Al Shabab in the region, that has received far less coordination and control (Ottaway et al. 2011). It is likely the economic importance of oceanic trade routes are responsible for the investment into curbing pirate activities rather than the magnitude of geopolitical risk to the region.

Piracy clearly affects those involved in an attack as well as shaping direct international response, for example through the Djibouti Code of Conduct. It also influences ocean-based activities in the region. In response to the rise in Somali piracy in 2007, European fishing companies decided for safety reasons to define a large Economic Exclusive Zone off the Somali coast - the catch forgone was equal to 25\% of their catch in the preceding four years. This resulted in the de facto protection of Somali waters. This curtailment of fishing extended into the rest of the region also affected artisanal and small-scale fisheries in the Seychelles and Kenya for example (Chassot et al. 2010). Fishing vessels recouped their losses by shifting location and displacing eastwards, whilst adjusting their behavior, so as to operate in pairs that fished alternatively, to increase their 
safety (Chassot et al. 2010; Marsac et al. 2009). Although these changes in behavior did not affect the total catches, changes in the size (i.e. smaller individuals), and fish species caught (more skipjack and bigeye tuna) were evident because vessels were no longer able to explore widely, or to track schools of fish. This demonstrated how efforts to secure the oceans from Somali pirates resulted in unexpected changes to the materiality and agency of the human and non-human (tuna) actors. Similar patterns have occurred in the Gulf of Guinea.

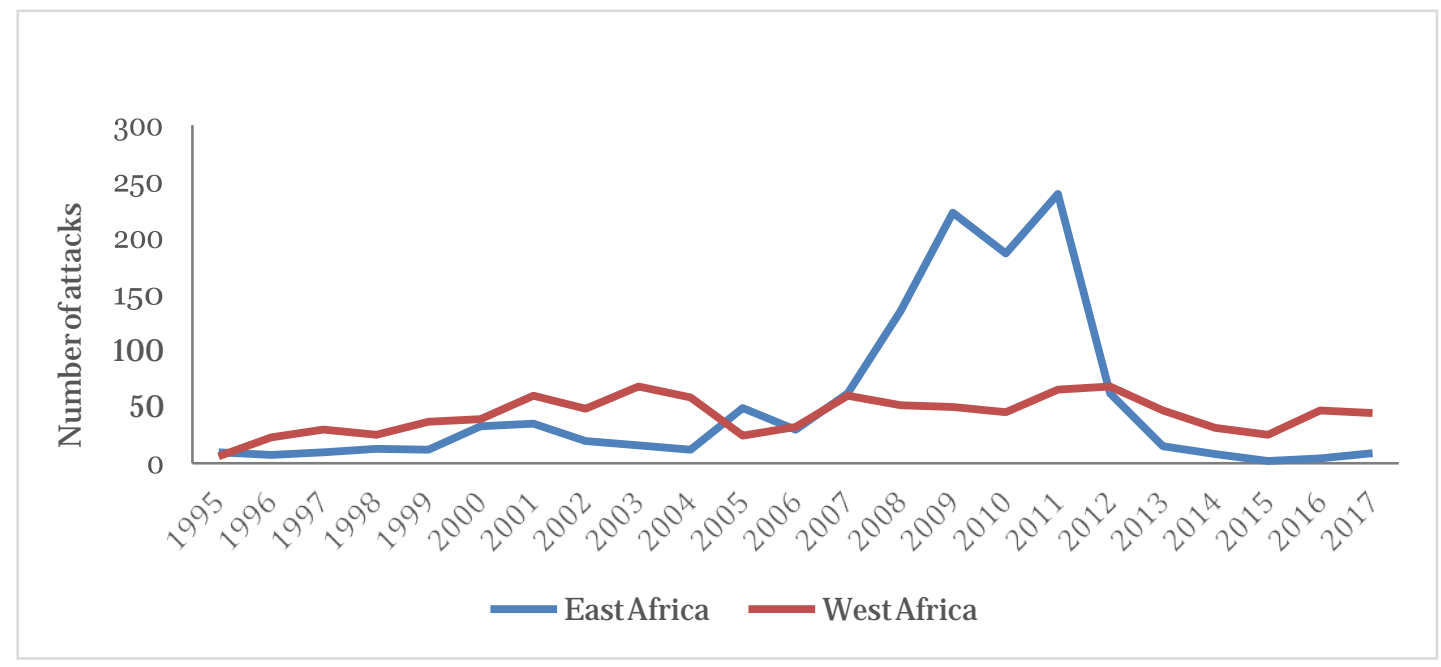

Figure 2: Number of actual and attempted pirate attacks in East and West Africa. Data from The Hague Centre for Strategic Studies (2010) and The State of Maritime Piracy (various years)

The international response to piracy in the Indian Ocean shows how securing the ocean is underwritten by an economic imperative. At the height of instances of Somali piracy, Somalia was very much in crisis. After decades of civil war the majority of the population was displaced, in need of food aid, or registered as refugees in neighboring countries. Furthermore, Somalia had a history of failed relations with the west, most notably the 1990 American invasion of Mogadishu. The context in which Somali piracy began to thrive was one in which Somalia felt their ocean resources had been plundered for decades (Ottaway et al. 2011). Thus, it has been argued that the pirates in the region were part of Somalia's efforts to secure their resources and their promise of wealth back to Somalia in a form of redistributive justice (ibid). The rapid international response that followed, with its efforts to secure the seas through armed private and military power, consolidated the status quo, with ocean wealth once more in the control of powerful, mostly western nations. The recent rise in pirate attacks suggests that the co-produced politics of security around piracy is far from over.

The absence of a direct physical threat, such as piracy, does not seem to exclude the need to secure the oceans (e.g. see Kalina et al. 2019). International efforts to secure the oceans can exert more subtle forms of control if they are constructed as 'threatened.' For example, a number of Blue Economy initiatives state:

'Illegal, Unregulated, and Unreported' (IUU) fisheries are the 'greatest threat to marine ecosystems [...] costing the global economy up to \$23billion annually' (e.g. FAO 2014).

Thus, considerable illegal, unregulated, and unreported (IUU) fishing practices are seen to cost the blue economy, and to threaten marine ecosystems and societies dependent on them. Furthermore, illegal and unreported fisheries are particularly prevalent in areas where governance is weak; most notably in Africa and Asia (Agnew et al. 2009; Figure 3). Such narratives position the oceans and the Blue Economy as at risk from illegal activities, legitimizing the need to intervene, govern, and control these fisheries. However, conflation of 'illegal', 
with 'unregulated', and 'unreported' can prove problematic particularly for the small scale fisheries of Africa (see below). Thus, the blue economy is positioned as necessary where African waters are placeless and ungoverned, and simultaneously threatened by illegal activities, overexploitation, and pollution.

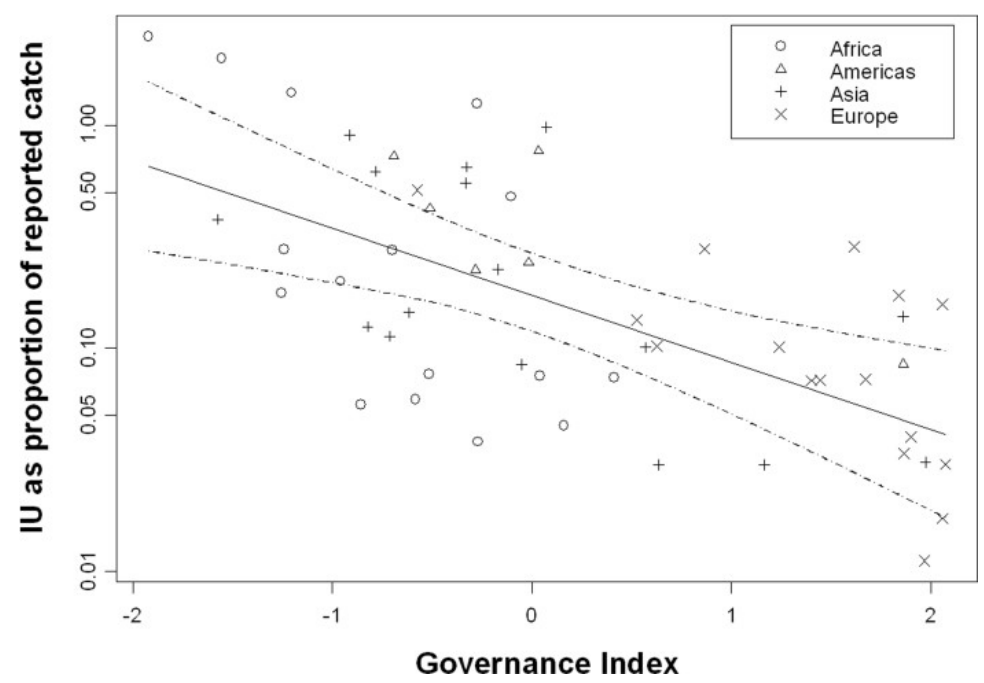

Figure 3: Relationship between incidence of Illegal and Unregulated (IU) fisheries (Agnew et al. 2009) and national governance (Kaufmann et al. 2009) showing a significant negative relationship ( $\mathrm{p}>0.05$ ) with Asia and Africa having weakest indicators of governance and highest proportion of IU fisheries. (Source: Agnew et al. 2009)

There are efforts underway to secure waters where inefficiencies in governance persist and IUU threats to fisheries prevail. These include improving the transparency and accountability of ocean-based activities through technologies of control, such as monitoring, surveillance, and tightening licensing and reporting regulations. Although egregious human rights and labor abuses do exist within global fisheries and need greater attention (Kittinger et al. 2017), conflating illegal with 'unregulated' and 'unreported' is problematic. Nearly ninety percent of the world's fishers are engaged in small scale and informal fisheries in low income countries (Mills et al. 2011: 9). These fisheries are, as would be expected, often unregulated and unreported (Mills et al. 2011; Pauly and Zeller 2016), but not necessarily illegal, and they provide a vital source of income, food, and nutrition. Indeed, the majority of Africa's fisherfolk are small-scale family owned enterprises. The greatest cost from imposing regulations on access, and registration fees could well be felt by the most vulnerable, squeezing them out, rather than addressing and stopping the root causes of illegal activities and labor abuses.

The discourse surrounding IUU fisheries risks legitimizing the need to secure the oceans and criminalizing informal, small-scale, or less economically profitable activities. The intentional or inadvertent agents of these changes are often technologies of surveillance. For example, in 2018, an international collaboration between conservation organizations (Oceana) and technology corporations (Google and SkyTruth) launched Global Fishing Watch, in an effort to provide 'free data and real-time tracking' of all commercial fishing vessels (Global Fishing Watch 2016-2019). Soon after at the Our Oceans Conference (OOC), Indonesia, Peru, and Costa Rica made their data on smaller fishing vessels publicly available (OOC 2018) demonstrating widespread and global governmental support: "The target of commitments for OOC 2018, is to combat maritime crime, innovations in surveillance and monitoring and a sharing mechanism to improve maritime security" (OOC 2018).

However, grass roots fisher organizations - who represent small-scale fisherfolk - strongly rejected these initiatives due to what they view as ocean grabbing (WFFP 2018). In an effort to protect their human rights and food sovereignty, fishers, and fish and salt farmers are organizing an 'Oceans' People Conference' 
in response to the 'Our Oceans Conference' (WFFP October 2018). Their calls for justice at sea initiatives follow previous acts of resistance and rejections of earlier Blue Economy initiatives by national and international organizations trying to impose rights-based fishing reforms (WFFP and WFF March 2013), to demarcate the oceans for profitable use through marine spatial planning technologies, and to secure the oceans through military power (WFF October 2018). That the largest group of ocean users feel excluded from Blue Economy initiatives should serve as a warning that the blue economy language around 'inclusion' and 'participation' is failing to achieve meaningful engagement. A set of governance principles, developed by small scale fishers, community, and government representatives, have been formally accepted by 142 states (Cohen et al. 2019; FAO 2015). These principles can form the basis for dialogue around the blue economy to engage with a social justice agenda (see Cohen et al. 2019).

\section{Conclusion}

As the 'blue economy' gains traction as a discursive and material series of political technologies, it demands critical interrogation. Furthermore, for all the value in analyzing its emergence in general terms, there remains the vital need to situate the blue economy in particular places and examine its specific effects. To overlook the specificities of context, in terms of both governance (state, corporation, civil society and their interdependence), industry (from fishing to deep-sea mining) and political actors (from human to the more-thanhuman), is to miss a great deal. 'Placing' the blue economy in the African context is, in part, an effort to think about the ways in which a particular type of (capitalist) expansion is rationalized, legitimized and contested around the 'blueing' of the imperatives of economic growth. As we have introduced in this article, much of the political work being done in order to 'secure the blue' is already happening in a variety of iterations across the continent. Political ecology, with its emphasis on a spatio-temporal analysis of situated power in the context of resource use, is clearly an opposite lens through which to face up to the questions of development and justice thrown up by blue growth. From this perspective, the blue economy represents a watery extension of "the environment as an arena of contested entitlements, a theatre in which conflicts or claims over property, assets, labor, and politics of recognition play themselves out" (Peluso and Watts 2001: 25).

The articles that make up this Special Section cover a breadth of issues that have been subsumed into the discourse and practices of the 'blue economy' in Africa. In two cases, the analyses center on a particular threshold between landed and oceanic political ecologies - port development in South Africa. With particular reference to the expansion of the port in Durban, the blue economy is scripted as a vehicle for sustainable 'blue' development by the South African state under the rubric of 'Operation Phakisa: Oceans.' As Bond (2019) shows however, grassroots political actors in the country serve to contest and counter-narrate blue development, helping to shape its outcomes and their legitimacy. Set against a backdrop of exclusion and its resistance, smallscale fisherfolk find themselves having to negotiate the imperatives of international capital and nation stateled designs centered on blue growth (Kalina et al. 2019).

Marine phosphate mining is analyzed in Namibia where questions of sovereignty and power circulate, and where the fixed sense of the 'blue' is blurred as it comes into dialogue with the dynamics of landed political ecologies (Carver 2019). By highlighting the important role that a unique, voluminous and deep ocean environment has in shaping the politics that emerges, the ocean is mobilized as a political actor normally missed by traditional analyses of seabed mining (ibid.). Continuing the important role that more-than-human actors have for shaping the blue political ecologies across the African continent, Andriamahefazafy and Kull (2019) show how migratory tuna are central to resource access in the Western Indian Ocean. Extending Ribot and Peluso's (2003) 'theory of access', they highlight one way in which the material turn in resource geography can be used to make sense of a blue growth narrative normally treated as simply an object of human concern.

Similarly populated by political actors, Schutter and Hicks (2019) employ a social network approach in order to understand the multiplicity of influences that construct the blue economy narrative in the Republic of Seychelles. The specific debt-for-nature swap that emerges as the central policy is co-produced from a diversity of sources and invites an engagement with the question of 'whose knowledge counts' in cementing oceanographic thought and practice in the region. As a very particular kind of political technology, such a debt swap opens up new political spaces in which the specter of environmental pollution is made to facilitate 
particular approaches to environmental governance. Similarly, Little and Akese (2019) offer insight into how the accumulation and disposal of electronic waste in Ghana leads certain blue political ecologies to emerge. Against a backdrop of changing technologies, human actors, animals and the physical fabric of oceanic space itself, the blue economy in Africa is far from the stable development concept that it promises to be. Who gets to 'know' and control the 'blue', and how that knowledge is 'secured' would seem to be key to understanding developments for Africa's blue economy.

The articles in the Special Section provide an entry point into thinking analytically about the political ecologies of the blue economy in Africa. Yet, understandably, they cannot constitute a complete agenda and many fertile avenues for research remain. Many of the examples reflect on what is happening 'in Africa' and there is clearly an opportunity for future research to consider relations of exteriority that link Africa's diverse maritime regions, knowledges and practices to various 'outsides.' This is a pressing need so that seeing Africa as a continent, which was fostered as a particular type of colonial fiction (see Mudimbe 1994), is not unwittingly reproduced in a maritime context. Indeed, the ways that the blue economy manifests itself in various 'extra-Africas', for example in China, the Mediterranean world, Gulf states, the Caribbean and so forth, are increasingly important to understand.

\section{Political ecologies of the Blue Economy in Africa, edited by John Childs and Christin C. Hicks}

1. Patrick Bond. Blue Economy threats, contradictions and resistances seen from South Africa

2. Marc Kalina, Alexio Mbereko, Brij Maharaj and Amanda Botes. Subsistence marine fishing in a neoliberal city: a political ecology analysis of securitization and exclusion in Durban, South Africa

3. Rosanna Carver. Resource sovereignty and accumulation in the blue economy: the case of seabed mining in Namibia

4. Mialy Andriamahefazafy and Christian Kull. Materializing the blue economy: tuna fisheries and the theory of access in the Western Indian Ocean

5. Marleen Schutter and Christina Hicks. Networking the Blue Economy in Seychelles: pioneers, resistance, and the power of influence

6. Peter Little and Grace Akese. Centering the Korle Lagoon: exploring blue political ecologies of E-Waste in Ghana

\section{References}

Agnew, D.J., J. Pearce, G. Pramod, T. Peatman, R. Watson, J.R. Beddington and T.J. Pitcher. 2009. Estimating the worldwide extent of illegal fishing. PloS One 4(2): p.e4570.

African Union 2014. Agenda 2063. The Africa we want. Available online at https://au.int/en/documents/20141012/key-documents-agenda2063

Andriamahefazafy, M. and C. Kull 2019. Materializing the blue economy: tuna fisheries and the theory of access in the Western Indian Ocean. Journal of Political Ecology 26: 403-425.

Barbesgaard, M. 2018. Blue growth: savior or ocean grabbing? The Journal of Peasant Studies 45(1): $130-149$.

Baucom, I. 2005. Specters of the Atlantic: finance capital, slavery, and the philosophy of history. Durham, NC: Duke University Press.

Bennett, N.J., H. Govan and T. Satterfield. 2015. Ocean grabbing. Marine Policy 57: 61-68.

Bond, P. 2019. Blue Economy threats, contradictions and resistances seen from South Africa. Journal of Political Ecology 26: 341-362.

Campling, L. and A. Colás. 2017. Capitalism and the sea: sovereignty, territory and appropriation in the global ocean. Environment and Planning D: Society and Space 36(4): 776-794. 
Carver, R. 2019. Resource sovereignty and accumulation in the blue economy: the case of seabed mining in Namibia. Journal of Political Ecology 26: 381-402.

Cavanagh, C.J. and T.A. Benjaminsen, 2017. Political ecology, variegated green economies, and the foreclosure of alternative sustainabilities. Journal of Political Ecology 24: 200-216.

Chassot, E., P. Dewals, L. Floch, V. Lucas, M. Morales-Vargas and D. Kaplan. 2010. Analysis of the effects of Somali piracy on the European tuna purse seine fisheries of the Indian Ocean. IOTC Scientific Committee Report: IOTC- 2010-SC-09. Victoria, Seychelles: Indian Ocean Tuna Commission.

Childs, J. 2018. Extraction in four dimensions: time, space and the emerging geo (-) politics of deep-sea mining. Geopolitics in press. https://doi.org/10.1080/14650045.2018.1465041

Clarke-Sather, A., B. Crow-Miller, J.M. Banister, K. Anh Thomas, E.S. Norman and S.R. Stephenson. 2017. The shifting geopolitics of water in the anthropocene. Geopolitics 22(2): 332-359.

Cohen, P.J., E.H. Allison, N.L. Andrew, J. Cinner, L.S. Evan, M. Fabinyi, L.R. Garces, S.J. Hall, C.C. Hicks, T.P. Hughes and S. Jentoft. 2019. Securing a just space for small-scale fisheries in the blue economy. Frontiers of Marine Science 6.

Colombos, C.J. 1967. The International Law of the Sea. $6^{\text {th }}$ ed. New York: David McKay.

Cudworth E. and S. Hobden. 2017. Post-human security. In Burke A. and R. Parker (eds.). Global insecurity. London: Palgrave Macmillan. Pp. 65-81.

De Santo, E.M., P.J. Jones and A.M.M. Miller. 2011. Fortress conservation at sea: a commentary on the Chagos marine protected area. Marine Policy 35(2): 258-260.

DeLoughrey, E. 2017. Submarine futures of the Anthropocene. Comparative Literature 69(1): 32-44.

DeLoughrey, E. M. 2007. Routes and roots: navigating Caribbean and Pacific island literatures. Honolulu: University of Hawaii Press.

Dunne, J.P. 2015. Order at sea and landlocked countries in Africa. Available online at https://www.sipri.org/commentary/blog/2015/order-sea-and-landlocked-countries-africa

Eikeset, A.M., A.B. Mazzarella, B. Davíðsdóttir, D,H. Klinger, S.A. Levin, E. Rovenskaya and N.C. Stenseth. 2018. What is blue growth? The semantics of "Sustainable Development" of marine environments. Marine Policy 87: 177-179.

Elden, S. 2013. Secure the volume: vertical geopolitics and the depth of power. Political Geography 34: 3551.

FAO. 2014. Asia and the Pacific's Blue Growth Initiative. Rome: Food and Agricultural Organization of the United Nations (FAO).

FAO. 2015. Voluntary guidelines for securing sustainable small scale fisheries in the context of food security and poverty eradication. Rome: Food and Agricultural Organization of the United Nations (FAO).

FAO. 2017. Innovative ocean financing: Seychelles Blue Bonds. Rome: Food and Agricultural Organization of the United Nations (FAO). Available online at http://www.fao.org/blogs/blue-growthblog/innovative-ocean-financing- seychelles-blue-bonds/en/

Germond-Duret, C. 2018. Framing the blue economy: development, sustainability and placelessness. Presented at the Regional Studies Association Research Network for Sustainability Transitions in the Coastal Zone, Seyðisfjörður, Iceland, September.

Gilroy, P. 1993. The black Atlantic: modernity and double consciousness. Cambridge, MA: Harvard University Press.

Global Fishing Watch. 2016-2019. https://globalfishingwatch.org/ (Last accessed December 14, 2018)

Government of Seychelles and the Commonwealth. 2018. Seychelles Blue Economy: strategic policy framework and roadmap: charting the future (2018-2030). Victoria: Blue Economy Department, Government of the Seychelles.

Grotius, H. 1916[1609]. The freedom of the seas or the right which belongs to the Dutch to take part in the East Indian Trade. Ed. J.B. Scott. New York: Oxford University Press. 
Grundy-Warr, C., M. Sithirith and Y.M. Li. 2015. Volumes, fluidity and flows: rethinking the 'nature' of political geography. Political Geography 45: 93-95.

Hadjimichael, M. 2018. A call for a blue degrowth: unravelling the European Union's fisheries and maritime policies. Marine Policy 94: 158-164.

Hannigan, J. 2016. The geopolitics of deep oceans. London: Wiley.

Harris, L.M. 2017. Political ecologies of the state: recent interventions and questions going forward. Political Geography 58: 90-92.

Hoegh-Guldberg, O., D. Beal, T. Chaudhry, H. Elhaj, A. Abdullat, P. Etessy et al. 2015. Reviving the ocean economy: the case for action. Gland: WWF International.

Hollis, D. and T. Rosen. 2010. United Nations convention on law of the sea (UNCLOS), 1982. The Encyclopedia of Earth. Online

Hugill, P.J. 1993. World trade since 1431: geography, technology, and capitalism. Baltimore: Johns Hopkins University Press.

International Seabed Authority. 2017. Marine mineral resources of Africa's continental shelf and adjacent international seabed area. Technical Study, Available online at https://www.isa.org.jm/sites/default/files/files/documents/ts20.pdf

Jambeck, J., B.D. Hardesty, A.L. Brooks, T. Friend, K. Teleki, J. Fabres, Y. Beaudoin, A. Bamba, J. Francis, A. Ribbink, T. Baleta, H. Bouwman, J. Knox and C. Wilcox. 2018. Challenges and emerging solutions to the land-based plastic waste issue in Africa. Marine Policy 96: 256-263.

Jumeau, R. 2013. Small island developing states, large ocean states. Expert Group Meeting on Oceans, Seas and Sustainable Development: implementation and follow-up to Rio. April. United Nations.

Kaufmann D., A. Kraay and M. Mastruzzi. 2007. Governance matters VI: governance indicators for 19962006. World Bank Policy Research Working Paper 4280. Washington DC: World Bank.

Kalina, M., A. Mbereko, B. Maharaj and A. Botes 2019. Subsistence marine fishing in a neoliberal city: a political ecology analysis of securitization and exclusion in Durban, South Africa. Journal of Political Ecology 26: 363-380.

Kay, K. 2018. A hostile takeover of nature? Placing value in conservation finance. Antipode 50(1): $164-183$.

Kittinger, J.N., L.C. Teh, E.H. Allison, N.J. Bennett, L.B. Crowder, E.M. Finkbeiner, C.C. Hicks, C.G. Scarton, K. Nakamura, Y. Ota and J. Young. 2017. Committing to socially responsible seafood. Science 356(6341): 912-913.

Kothari, U. and R. Wilkinson. 2010. Colonial imaginaries and postcolonial transformations: exiles, bases, beaches. Third World Quarterly 31(8): 1395-1412.

Kraska J. and B. Wilson. 2009. Combating pirates of the Gulf of Aden: the Djibouti Code and the Somali Coast Guard Ocean and Coastal Management 52(10): 516-520.

Lehman, J.S. 2018. Marine cultural heritage: frontier or centre? International Social Science Journal. In press https://doi.org/10.1111/issj.12155

Lehman, J.S. 2013. Relating to the sea: enlivening the ocean as an actor in Eastern Sri Lanka. Environment and Planning D: Society and Space 31(3): 485-501.

Little, P.C. and G. Akese 2019. Centering the Korle Lagoon: exploring blue political ecologies of E-Waste in Ghana. Journal of Political Ecology 26: 448-465.

Marsac, F., M. Yeh, T. Nishida, J. Dorizo, J. Ariz and E. Chassot. 2009. Impacts of piracy threats in the West Indian Ocean on the activity and yield of the longline and purse seine fisheries. IOTC Scientific Committee Report: IOTC-2009-SC-10. Victoria, Seychelles: Indian Ocean Tuna Commission.

Meehan, K.M. 2014. Tool-power: water infrastructure as wellsprings of state power. Geoforum 57: $215-224$.

Mills, D.J., L. Westlund, G. de Graaf, Y. Kura, R. Willman and K. Kelleher. 2011. Under-reported and undervalued: small-scale fisheries in the developing world. In Pomeroy, R.S. and N. Andrews (eds.). Small-scale fisheries management: frameworks and approaches for the developing world. Wallingford: CABI. Pp.1-15. 
Mudimbe, V.Y. 1994. The idea of Africa. Bloomington, IN: Indiana University Press.

Ngwawi, J. 2018. Growing the Blue Economy for all SADC states, not only those with coastlines. Namibia Economist, Available Online at https://economist.com.na/37452/special-focus/growing-the-blueeconomy-for- all-sadc-states-not-only-those-with-coastlines/

Nixon, R. 2011. Slow violence and the environmentalism of the poor. Cambridge, MA: Harvard University Press.

O'Connell, D.P. 1982. The international law of the sea. Oxford: Clarendon Press.

Ottaway, R., B. Ainsworth, M. Campbell, A. Clwyd, R. Stewart, D. Watts, D. Reindorp, C. McCafferty and S. Healy. 2011. Piracy off the coast of Somalia, Corrected Transcript of Oral Evidence to be published as HC 1318ii, Session 2010-12, House of Commons, 29 June 2011. https://publications.parliament.uk/pa/cm201012/cmselect/cmfaff/c1318-ii/c131801.htm (Last accessed December 14, 2018)

Our Oceans. 2018. https://ourocean2018.org/?l=our-ocean-commitments (Last accessed December 14, 2018)

Patil, P., J. Virdin, J., Diez, S.M., J. Roberts and A. Singh. 2016. Toward a Blue Economy: a promise for sustainable growth in the Caribbean. Washington, DC: World Bank.

Pauli, G.A. 2010. The blue economy: 10 years, 100 innovations, 100 million jobs. Taos, NM: Paradigm Publications.

Pauly, D. and D. Zeller. 2016. Catch reconstructions reveal that global marine fisheries catches are higher than reported and declining. Nature Communications 7: 10244.

Pauly, D., D. Belhabib, R. Blomeyer, W.W. Cheung, A.M. Cisneros-Montemayor, D. Copeland, S. Harper, V.W. Lam, Y. Mai, F. Le Manach and H. Österblom. 2014. China's distant-water fisheries in the 21st century. Fish and Fisheries 15(3): 474-488.

Peluso, N.L., and M.J Watts (eds.). 2001. Violent environments. Ithica: Cornell University Press.

Potgieter, T. 2018. Oceans economy, blue economy, and security: notes on the South African potential and developments. Journal of the Indian Ocean Region 14(1): 49-70.

Prestholdt, J. 2015. Locating the Indian Ocean: notes on the postcolonial reconstitution of space. Journal of Eastern African Studies 9(3): 440-467.

Republic of South Africa. 2015. Operation Phakisa: unlocking the economic potential of South Africa's oceans. Pretoria: Republic of South Africa.

Ribot, J.C. and N.L. Peluso. 2003. A theory of access. Rural Sociology 68(2): 153-181.

SADC. 2018. South African Development Community: Member States, Available online at https://www.sadc.int/member-states/

Schrijver, N. 2008. Sovereignty over natural resources: balancing rights and duties. Cambridge: Cambridge University Press.

Schutter, M. and C.C. Hicks. 2019. Networking the Blue Economy in Seychelles: pioneers, resistance, and the power of influence. Journal of Political Ecology 26: 425-447.

Semple E.C. 1931. The geography of the Mediterranean region: its relation to ancient history. New York: Henry Holt.

Silver, J.J. and L.M. Campbell. 2018. Conservation, development and the blue frontier: the Republic of Seychelles' Debt Restructuring for Marine Conservation and Climate Adaptation Program. International Social Science Journal. In press. https://doi.org/10.1111/issj.12156

Silver, J.J., N.J. Gray, L.M. Campbell, L.W. Fairbanks and R.L. Gruby. 2015. Blue economy and competing discourses in international oceans governance. The Journal of Environment and Development 24(2): 135-160.

Steinberg, P.E. 2001. The social construction of the ocean. Cambridge: Cambridge University Press.

Steinberg, P.E. and K. Peters. 2015. Wet ontologies, fluid spaces: giving depth to volume through oceanic thinking. Environment and Planning D: Society and Space 33(2): 247-264. 
Sullivan, S. 2013. Banking nature? The spectacular financialisation of environmental conservation. Antipode 45(1): 198-217.

The Hague Centre for Strategic Studies 2010. HCSS Piracy Database. The Hague: The Hague Centre for Strategic Studies.

Theriault, N. 2017. A forest of dreams: ontological multiplicity and the fantasies of environmental government in the Philippines. Political Geography 58: 114-127.

UNCTAD. 2017. Review of maritime transport. New York: UNCTAD

UNECA 2016. Africa's Blue Economy: a policy handbook. Addis Ababa: UN Economic Commission for Africa (UNECA).

UNESCO. 2001. Convention on the Protection of Underwater Cultural Heritage, available online at http://www.unesco.org/new/en/culture/themes/underwater- cultural-heritage/2001-convention/officialtext/

UNESCO. 2017. Safeguarding underwater cultural heritage for sustainable development in Nairobi. Available online at http://www.unesco.org/new/en/member-states/singleview/news/safeguarding_underwater_cultural_heritage_for_sustainable_de/

United Nations. 1958. Conventions on fishing and conservation of the living resources of the high seas, A/CONF.13/L.54, New York: United Nations.

United Nations 1958. Conventions on the continental shelf, A/CONF.13/L.55. New York: United Nations.

United Nations 1983. The Law of the Sea: official text of the United Nations Convention on the Law of the Sea with Annexes and Index, A/CONF.62/L.122. New York: United Nations.

United Nations. 2012. The future we want: outcome document of the United Nations Conference on Sustainable Development. Rio de Janeiro: United Nations.

United Nations General Assembly. 1982. Convention on the Law of the Sea. https://www.refworld.org/docid/3dd8fd1b4.html (Last accessed December 14, 2018)

United States. 1945a. Presidential proclamation no. 2667: concerning the policy of the united states with respect to the natural resources of the sub soil and the sea-bed on the continential shelf (September 28). Federal Register 10: 12303.

United States 1945b. Presidential proclamation no. 2668: concerning the policy of the united states with respect to coastal fisheries in certain areas of the high seas (September 28). Federal Register 10: 12304.

Voyer, M., G. Quirk, A. McIlgorm and K. Azmi. 2018. Shades of blue: what do competing interpretations of the Blue Economy mean for oceans governance? Journal of Environmental Policy and Planning 20(5): 595-616.

Walcott, D. 1987. The sea is history. In D. Walcott (ed.). Collected Poems, 1948-1984. New York: Farrar, Straus and Giroux. Pp. 364-367.

WFFP. 2018. Fisher Peoples reject the "Our Ocean Conference" and organize the Ocean's People Conference. http://worldfishers.org/2018/10/25/fisher-peoples-reject-ocean-conference-organize-oceans-peopleconference/\#comments (Last accessed December 14, 2018).

WFFP and WFF. 2013. A call for governments to stop supporting the global partnership for oceans (GPO) and Rights-Based Fishing (RBF) Reforms. http://worldfishers.org/wp-content/uploads/2015/11/WFFPWFF-Call-on- Governments_GPO_200313.pdf (accessed December 14, 2018).

WFFP and WFF. 2015a. Fisherfolks say no to the Coastal Fisheries Initiative. http://worldfishers.org/wpcontent/uploads/2015/11/CFI_Statement.pdf (accessed December 14, 2018).

WFFP and WFF. 2015b. No to Blue Carbon, yes to food sovereignty and climate justice. http://worldfishers.org/wp-content/uploads/2015/12/Blue_Carbon_Statement.pdf (accessed December 14, 2018).

Winder, G.M. and R. Le Heron. 2017. Assembling a Blue Economy moment? Geographic engagement with globalizing biological-economic relations in multi-use marine environments. Dialogues in Human Geography 7(1): 3-26. 